\title{
Repensando o conceito de diglossia à luz de Michel de Certeau
}

\section{Rethinking the concept of diglossia in light of Michel de Certeau}

Miguel Afonso Linhares

IFRN

miguel.linhares@ifrn.edu.br

Claudiana Nogueira de Alencar

UECE

claudiana.alencar@uece.br

Resumo: O presente trabalho consiste em uma reflexão sobre o conceito de diglossia, uma palavra cuja especialização semântica nos estudos linguísticos se deu por Jean Psichari, em 1885. Não obstante, veio ganhar precisão teórica apenas em 1959, com Charles Ferguson. Depois da publicação do seu artigo, o conceito teve um sucesso imediato na Sociolinguística. Este artigo segue a esteira dessas discussões, com o objetivo de repensar o sujeito falante da "variedade baixa" ou "língua dominada". Para tanto, valemo-nos da reflexão de Michel de Certeau (1994) sobre o cotidiano, especialmente das categorias de estratégia e de tática. Na primeira seção do artigo, traçamos um percurso pela história do termo diglossia, desde os seus significados nos primeiros testemunhos até a sua consolidação como conceito científico com Ferguson (1972 [1959]) e Fishman (1967). A segunda é um encaminhamento à reflexão: expomos uma leitura crítica dos artigos mencionados e algumas críticas por parte de outros sociolinguistas. Na terceira, damos algumas informações sobre 
o caso de diglossia que serve de fundamento e ilustração à reflexão: a diglossia espanhol-catalão na Catalunha. Enfim, na quarta, o leitor alcança a reflexão almejada: o sujeito falante da "variedade baixa" ou "língua dominada" não é um mero paciente em uma relação alto-baixo ou dominante-dominado, mas também um agente no campo hegemônico, que usa de táticas para contra-arrestar a dominação.

Palavras-chave: diglossia; catalão; Certeau.

Abstract: This paper aims to reflect about the concept of diglossia, a term whose semantic specialization in language studies was introduced by Jean Psichari in 1885. However, a precise theoretical definition came only by Charles Ferguson in an article published in 1959. Since this publication, the concept was immediately accepted and successfully applied in Sociolinguistics field. This paper follows these discussions in order to rethink the subject whose language is considered a "low prestige variety" or a "dominated language". Therefore, we selected the reflections presented by Michel de Certeau (1994) about everyday life, especially two categories: strategy and tactics. In the first section, the discussion covers the history of the term diglossia, since its initial meaning up to its consolidation as a scientific concept as referred in Ferguson (1972[1959]) and Fishman (1967). In the second section, as an invitation to reflection, we expose a critical reading of these articles and some criticism from other scholars. In the third place, we provide some information about the case of diglossia, which forms the basis for this reflection, and exemplify it: the Spanish-Catalan diglossia in Catalonia. Finally, in the last section, the reader reaches the desired reflection: the speakers of a "low prestige variety" or "dominated language" is not a merely user in a high-low prestige variety or dominant-dominated language perspective, but also an agent in the hegemonic field, which is able to use tactics against the domination.

Keywords: diglossia; Catalan; Michel de Certeau.

Recebido em 25 de fevereiro de 2015. Aprovado em 01 de julho de 2015. 


\section{Introdução}

O presente trabalho consiste em uma reflexão sobre o conceito de diglossia, uma palavra originariamente grega cuja especialização semântica, designando algo passível de estudo linguístico, se deu por obra de Jean Psichari em 1885, que chamou por ela aos usos de duas variedades da língua grega, sensivelmente distintas, servindo uma e a outra a funções específicas. Não obstante, esse conceito veio ganhar precisão teórica apenas em 1959, por conta de Charles Ferguson, que o transformou em um conceito científico universalmente aplicável, sempre que houvesse as condições idôneas de aplicação.

A partir da publicação do artigo de Ferguson, o conceito de diglossia teve um sucesso imediato na Sociolinguística, tornando-se o ponto de partida não só de qualquer estudo sobre o fenômeno que ele mesmo designa mas também de qualquer discussão em torno da sua aplicabilidade. Este artigo segue a esteira dessa discussão, com o objetivo de repensar o sujeito falante da "variedade baixa", conforme Ferguson (1972 [1959]), ou "língua dominada", conforme Aracil (1982[1965]) e Ninyoles (1969). Para tanto, valemo-nos da reflexão de Michel de Certeau (1994) sobre o cotidiano, especialmente das categorias de estratégia e de tática.

Na primeira seção do artigo, traçamos um percurso pela história do termo diglossia, desde os significados que apresenta em testemunhos antes da sua especificação para nomear a realidade linguística da Grécia moderna até a sua consolidação como conceito científico com a obra de Ferguson (1972 [1959]) e a ampliação da sua aplicabilidade, bem como a sua diferenciação do bilinguismo por Fishman (1967). Devido ao fato de que os trabalhos desses autores são centrais na evolução do conceito, detemo-nos neles para alicerçar bem a reflexão pretendida.

A seção seguinte é um encaminhamento à reflexão: expomos uma leitura crítica dos artigos de Ferguson (1972 [1959]) e de Fishman (1967) e algumas críticas às suas definições de diglossia por parte de outros sociolinguistas, críticas que nos chamaram a atenção tanto pela sua transcendência dentro da Sociolinguística, como as de Aracil (1982[1965]) e Ninyoles (1969), como pela sua agudeza, como a de Hamel e Sierra (1983).

A terceira seção é a parte em que damos algumas informações sobre o caso de diglossia que serve de fundamento e ilustração à nossa reflexão: a diglossia espanhol-catalão na Catalunha. Escolhemo-la não só 
por termos um bom conhecimento dela mas também porque, sem deixar de apresentar as condições mais marcantes de uma diglossia, ela afastase da definição fergusoniana-fishmaniana em mais de um aspecto, além de servir ao escopo deste trabalho igualmente em mais de um aspecto.

Enfim, na quarta seção, o leitor alcança a reflexão para a qual culmina este texto: o sujeito falante da variedade baixa ou língua dominada não é um mero paciente em uma relação alto-baixo ou dominante-dominado, mas é também um agente, que age no campo hegemônico, esquiva-se das estratégias dos agentes hegemônicos e usa de táticas para contra-arrestar a dominação. Nesse sentido, evocamos a diglossia espanhol-catalão na Catalunha para arguir que o hibridismo do espanhol falado pelos catalães pode ser uma tática mediante a qual eles mantêm a sua alteridade em face dos espanhóis.

\section{Evolução do conceito de diglossia}

O termo diglossia tem origem grega. Em grego, tem a forma $\delta \imath \gamma \lambda \omega \sigma \sigma i \alpha$, a qual apresenta dois componentes: o prefixo $\delta l-$, por $\delta l \sigma-$, que quer dizer "duas vezes", e a raiz $\gamma \lambda \omega \sigma \sigma-$, que quer dizer "língua". A atestação remanescente mais antiga dessa palavra está na Epístola de Barnabé, na qual funciona como um substantivo correspondente ao adjetivo $\delta i \gamma \lambda \omega \sigma \sigma o \varsigma$. Esse adjetivo designava propriamente a língua bifurcada de certos répteis, e, por metáfora, também a pessoas maledicentes, caluniadoras (cf. FERNÁNDEZ, 1995, p. 181-185).

No começo do século 19, mais precisamente em 1821, a Grécia tornou-se independente do Império Otomano, a cujo domínio pertencera desde a queda de Constantinopla, em 1453. No momento de escolher

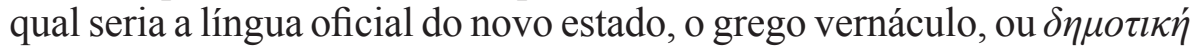
$\gamma \lambda \omega ́ \sigma \sigma \alpha$ ("língua popular"), acumulava divergências sensíveis em relação à coiné e ainda mais ao grego clássico. Foi-se formando, então, uma norma padrão fundamentada no léxico e na gramática do grego antigo, mas que satisfazia às necessidades comunicativas do mundo moderno. Essa norma padrão é conhecida como $\kappa \alpha \theta \alpha \rho \varepsilon v ́ o v \sigma \alpha$, ou "língua purificada". Ambos os códigos, $\delta \eta \mu о \tau \iota \kappa \eta ́ ~$ e $\kappa \alpha \theta \alpha \rho \varepsilon v ́ o v \sigma \alpha$, eram considerados variedades da mesma língua grega, mas, na prática, os cidadãos gregos tinham uma língua materna, que empregavam nos âmbitos de uso informais, e tinham de aprender outra língua, que empregavam nos âmbitos de uso formais, a qual era, sem dúvida, semelhante, mas diferente em elementos tão básicos 


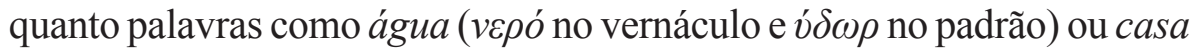
( $\sigma \pi i ́ \tau \imath$ no vernáculo e oíkoৎ no padrão). Contudo, o uso da $\kappa \alpha \theta \alpha \rho \varepsilon v ́ o v \sigma \alpha$ não ficou isento de desacordo: logo se opuseram defensores e detratores (cf. FERGUSON, 1972).

No fim do século 19, um dos detratores era Jean Psichari, um helenista francês de origem grega, que, na página 211 dos seus Essais de grammaire historique néo-grecque, de 1885, diz o seguinte:

Somente hoje temos em torno de nós e ao alcance do ouvido o melhor critério para decidir com segurança que essa língua é uma língua artificial e de convenção. Esse critério é a língua moderna, a língua popular que ouvimos falar todo dia. Por isso, quando encontramos em um autor a

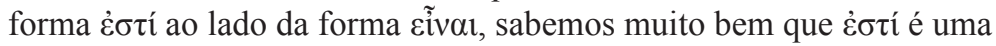
forma trazida da escola, e que eĩvol é a única forma viva, pois é hoje a única forma empregada pelo povo. Aqui estamos em condições de discernir o verdadeiro do falso, e de fazer a separação das duas línguas (apud FERNÁNDEZ, 1995, p. 180, tradução nossa). ${ }^{1}$

\section{A essa observação acrescenta em nota que:}

Como disse espirituosamente Roídis em um recente artigo saído nos números 1056-1057, 16-17 de abril de 1885, do jornal Akropolis, sofre-se hoje de diglossia (apud FERNÁNDEZ, 1995, p. 180, tradução nossa). ${ }^{2}$

O citado por Psichari é o romancista grego Emmanouíl Roídis. Dele é, portanto, o mérito de ter sugerido - não sem mordacidade- a palavra $\delta \imath \gamma \lambda \omega \sigma \sigma i \alpha$, que referia às duas pontas das línguas de certos répteis

\footnotetext{
1"Seulement aujourd'hui nous avons autour de nous, et à portée de l'oreille, le meilleur critérium pour décider avec certitude que cette langue est une langue artificielle et de convention: ce critérium c'est la langue moderne, la langue populaire que nous entendons parler tous les jours. Aussi dès que nous trouvons dans un auteur la forme

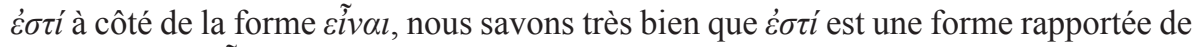
l'école, et que Ẽ̃vol est la seule forme vivante, puisque c'est aujourd'hui la seule forme employée par le peuple. Ici nous sommes en mesure de discerner le vrai du faux, et de faire la séparation des deux langues".

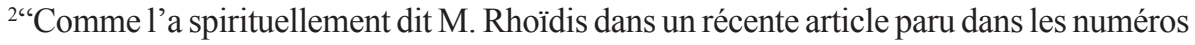
1056-1057, 16-17 avril de 1885, du journal Akropolis, on souffre aujourd'hui de diglossie”.
} 
e, por metáfora, à maledicência e à injúria, para dar nome ao estado sociolinguístico da Grécia, singular por haver o emprego de "duas línguas da mesma língua". De outro lado, coube a Psichari perceber e fazer uso dessa sugestão, acunhando, ao mesmo tempo, uma forma francesa do termo, diglossie, pela qual passou a outras línguas europeias, inclusive ao português: diglossia. Em 1928, ele voltou a discorrer sobre o assunto valendo-se dessa palavra no jornal quinzenal "Mercure de France":

Pedantes, em turbilhão, abateram-se sobre essa pobre Grécia, cuja clara vista obnubilaram completamente. Criaram a diglossia, veremos logo em quais condições precisas e sob a obsessão de quais miragens (apud FERNÁNDEZ, 1995, p. 176, tradução nossa). ${ }^{3}$

Assim, graças a Psichari, a palavra $\delta \imath \gamma \lambda \omega \sigma \sigma i \alpha$, levada para o francês com a forma diglossie, foi cada vez mais tornando-se um termo técnico que distinguia a singularidade sociolinguística grega. Daí a estender-se a outras situações semelhantes foi um pulo. Efetivamente, de dezembro de 1930 a fevereiro de 1931, o arabista francês William Marçais publicou três artigos sobre o ensino da língua árabe nas colônias da França. O primeiro artigo intitula-se "La diglossie arabe", mas a palavra diglossia vem aparecer apenas à página 121 do terceiro. Tratando das instruções oficiais para o ensino de segundas línguas, diz:

[...] são concebidas no seu conjunto para o ensino de línguas indoeuropeias, que são faladas sensivelmente como são escritas, e não para um idioma semítico afligido por uma incurável diglossia (apud FERNÁNDEZ, 1995, p. 177, tradução nossa). ${ }^{4}$

Assim como na Grécia recém independente, nos países árabes viveu-se também o embaraço de o vernáculo (الدارجة[ad-dārija] ou [al- 'ámmiyya]) ter acumulado ao longo de muito tempo diferenças

\footnotetext{
3"Des pédants, en tourbillon, se sont abattus sur cette pauvre Grèce dont ils ont complètement obnubilé la claire vue. Ils ont créé la diglossie, nous verrons tout à l'heure dans quelles conditions précises et sous l'obsession de quels mirages".

4"[...] elles sont conçues dans l'ensemble pour l'enseignement de langues indoeuropéennes que l'on parle sensiblement comme on les écrit, et non pour un idiome sémitique affligé d'une incurable diglossie".
} 
sensíveis em face da norma de prestígio e ser preciso ajustar essa norma de prestígio (الفصحى [al-fuṣhạ̄]) às necessidades comunicativas contemporâneas. Ao mesmo tempo, devia-se arcar com a consequência de estabelecer uma norma padrão que era quase outra língua para os falantes dos vernáculos árabes (cf. FERGUSON, 1972).

Este é, em suma, todo o contexto que favoreceu o próximo passo dado pelo sociolinguista norte-americano Charles Ferguson: dar ao termo diglossia uma conceituação científica no seio da Sociolinguística. Isso ele fez em um trabalho que publicou em 1959 com o título precisamente de "Diglossia":

Diglossia é uma situação linguística relativamente estável em que, além dos dialetos primários da língua (que podem incluir um padrão ou padrões regionais), há uma variedade sobreposta, muito divergente, altamente codificada (amiúde gramaticalmente mais complexa), veículo de uma grande e respeitada parcela da literatura escrita, quer de um período anterior quer de outra comunidade de fala, e que é aprendida essencialmente pela educação formal e usada para a maioria dos propósitos escritos e formais, mas não é usada por nenhum segmento da comunidade para a conversação ordinária (FERGUSON, 1972 [1959], p. 244-245, tradução nossa). ${ }^{5}$

Para ilustrar essa definição, Ferguson evoca exatamente os estados sociolinguísticos da Grécia e dos países árabes, aos quais acrescenta os casos das comunidades falantes do vernáculo alemão na Suíça e do crioulo de matriz francesa no Haiti. Em todos esses lugares diferentes, empregava-se um código linguístico em âmbitos formais ao qual se pode chamar "variedade alta" ou "A" (o grego padrão, o árabe padrão, o alemão padrão e o francês padrão) e outros códigos linguísticos em âmbitos informais a cujo conjunto se pode chamar "variedade baixa" ou "B" (o grego vernáculo, o árabe vernáculo, o alemão vernáculo e o

\footnotetext{
5"Diglossia is a relatively stable language situation in which, in addition to the primary dialects of the language (which may include a standard or regional standards), there is a very divergent, highly codified (often grammatically more complex) superposed variety, the vehicle of a large and respected body of written literature, either of an earlier period or in another speech community, which is learned largely by formal education and is used for most written and formal spoken purposes but is not used by any section of the community for ordinary conversation".
} 
crioulo). Não obstante, é evidente que a diglossia pode ocorrer em outros lugares, de modo que Ferguson discerne nove aspectos que a distinguem (cf. FERGUSON, 1972, p. 232-235).

O primeiro é a própria partição de papéis, ou funções sociais. Como dissemos, a variedade alta é usada em âmbitos como os serviços públicos e religiosos, a escolarização, a mídia, e a variedade baixa é usada em âmbitos como o lar ou o lazer.

O segundo é o prestígio. Ora, o próprio estabelecimento de uma norma padrão sensivelmente diferente do vernáculo demonstra que essa norma padrão goza de um prestígio enorme, em grande medida a reboque do prestígio da norma literária clássica em que se baseia. O próprio nome que a variedade alta recebe demonstra quão prestigiosa é: como se disse, $\kappa \alpha \theta \alpha \rho \varepsilon v ́ o v \sigma \alpha$ quer dizer "purificada"; Jف significa "eloquente", e o alemão padrão é chamado na Suíça Schriftdeutsch, ou seja, "alemão da escrita" (e Hochdeutsch, ou "alto-alemão", de modo geral em todo o domínio linguístico). De outro lado, o vernáculo costuma ter tão pouco prestígio que embora a quantidade de diferenças justifique uma individuação e uma padronização à parte, a maioria dos seus falantes crê que não fala senão um código de segunda classe, despossuído do requinte necessário aos usos mais cultos (FERGUSON, 1972, p. 237-238).

Mas o que leva os falantes a conferir mais prestígio a certo código e menos a outros? Como dissemos, o prestígio da variedade alta deve-se mormente ao prestígio já consolidado do código que lhe serve de base, geralmente a norma literária clássica, cujo prestígio é, à sua vez, consequência da ótima fortuna crítica das obras escritas nela. Com efeito, esse é o terceiro aspecto que distingue a diglossia: a variedade alta costuma ser o veículo de uma literatura culta muito ampla e muito valorizada. Já na variedade baixa compõem-se, de costume, de obras da chamada literatura oral (FERGUSON, 1972, p. 238).

O quarto aspecto - o modo como cada variedade é aprendida pelo indivíduo diglóssico-já foi enunciado indiretamente por meio dos termos pelos quais nos referimos à variedade alta e à variedade baixa. Perceba-se que antes de alcançar a teorização de Ferguson, referimo-nos à variedade baixa como o vernáculo, o que quer dizer que é ela, não a variedade alta, o código que os membros da comunidade diglóssica adquirem normalmente como língua materna. Por conseguinte, a variedade alta costuma não ser a língua materna de ninguém, de modo que a sua aprendizagem se dá mediante a escolarização do indivíduo (FERGUSON, 1972, p. 239). 
O ensino-aprendizagem da variedade alta em espaços de educação formal é facilitado, à sua vez, pelo fato de resultar de um processo de padronização pelo qual se produziram instrumentos normativos e didáticos, como gramáticas e dicionários. Pode haver mesmo uma instituição que tenha o poder de fixar a variedade alta e chancelar mudanças nela, como a Académie Française no caso do francês. Já a variedade baixa, é desprovida desses instrumentos, ou se os tem, não têm o caráter normativo das gramáticas e dos dicionários da variedade alta. Isso é, em suma, o quinto aspecto da diglossia (FERGUSON, 1972, p. 239-240).

O sexto consta do começo da definição de Ferguson: a diglossia é uma situação relativamente estável. Em outras palavras, onde há diglossia, ela tem durado por várias ou muitas gerações, e onde houve diglossia, ela durou igualmente por várias ou muitas gerações.

O sétimo, o oitavo e o nono aspectos respeitam à gramática, ao léxico e à fonologia de cada variedade, nessa ordem. Embora a norma padrão e o vernáculo sejam variedades de uma mesma língua, a diglossia, na teorização de Ferguson, ocorre precisamente porque há diferenças importantes entre as gramáticas e os léxicos de uma variedade e da outra. Isso é especialmente sensível em nível lexical: se alguém for produzir um texto sobre uma pesquisa científica na variedade baixa, sentirá falta dos termos técnicos necessários para tal; do mesmo modo, se for produzir um texto sobre a lida no campo na variedade alta, faltarão também palavras apropriadas. Quanto à fonologia, segundo Ferguson, as particularidades do sistema da variedade alta não formam senão um subsistema ou parassistema da variedade baixa (Op. cit., p. 241-244).

Em 1967, outro sociolinguista americano, Joshua Fishman, publicou um artigo intitulado "Bilingualism with and without diglossia; diglossia with and without bilingualism", que constituiu outra virada no uso da palavra diglossia. À página 30, revisando o tratamento de John Gumperz ${ }^{6}$ sobre o assunto, Fishman afirma que esse linguista demonstrou

que a diglossia existe não só em sociedades multilíngues que reconhecem oficialmente várias 'línguas' [e não só em sociedades que utilizam uma variedade vernácula e outra clássica] mas também em sociedades que são multilíngues no sentido em que empregam dialetos distintos, registros ou

${ }^{6}$ Segundo Fernández (1995, p. 167), não se acha nos trabalhos de Gumperz essa intenção de ampliar a aplicação do conceito de diglossia. 
variedades linguísticas de qualquer espécie diferenciadas funcionalmente (FISHMAN, 1967, p. 30, tradução nossa). ${ }^{7}$

Ferguson cingira a diglossia ao uso coordenado de dois códigos por uma mesma comunidade quando esses dois códigos são variedades da mesma língua. Fishman defende que a diglossia acontece independentemente dos estatutos dos códigos coordenados, ou seja, ele ampliou a aplicação do conceito. Da perspectiva de Fishman, a sociedade do Paraguai, onde o espanhol desempenha os papéis de uma variedade alta e o guarani, os de uma variedade baixa, é tão diglóssica quanto as sociedades dos países árabes.

Não obstante, note-se que Fishman, como o próprio título do artigo sugere, se preocupa ainda com distinguir a diglossia do bilinguismo. Para ele,

o bilinguismo é essencialmente uma caracterização do comportamento linguístico individual, enquanto a diglossia é uma caracterização da organização linguística em nível sociocultural (FISHMAN, 1967, p. 34, tradução nossa). ${ }^{8}$

Isso não quer dizer que o bilinguismo não seja social segundo o entendimento de Fishman. Quer dizer que a diferença entre o bilinguismo e a diglossia está sobretudo no fato de que nesta os usos dos códigos implicados são pautados por diferentes funções sociais. Para Fishman, o bilinguismo e a diglossia podem, pois, ocorrer de forma exclusiva ou podem coocorrer.

Assim, há bilinguismo com diglossia quando a necessidade de conhecer e de empregar os códigos implicados em âmbitos de uso distintos abarca o conjunto da comunidade. Há bilinguismo sem diglossia quando, ao contrário, se usa mais de uma língua em uma comunidade, mas não há nem a necessidade de as conhecer nem de as empregar em âmbitos de uso distintos para o conjunto da comunidade. Há diglossia

\footnotetext{
76"that diglossia exists not only in multilingual societies which officially recognize several 'languages' [, and not only in societies that utilize vernacular and classical varieties], but, also, in societies which are multilingual in the sense that they employ separate dialects, registers of functionally differentiated language varieties of whatever kind".

${ }^{8 *}$ 'bilingualism is essentially a characterization of individual linguistic behaviour whereas diglossia is a characterization of linguistic organization at the sociocultural level".
} 
sem bilinguismo quando os códigos implicados são usados em âmbitos de uso distintos, mas o conjunto da comunidade não tem conhecimento deles. Não há nem bilinguismo nem diglossia quando a comunidade usa apenas uma língua (cf. FISHMAN, 1967, p. 29-30).

Exemplos de bilinguismo com diglossia são todos os casos que satisfazem tanto a definição de diglossia de Ferguson, em que os códigos são variedades da mesma língua (alemão padrão e alemão vernáculo na Suíça), como a ampliação dessa definição por Fishman (espanhol e guarani no Paraguai). Exemplos de bilinguismo sem diglossia são todos os casos em que uma população imigrante mantém o uso da sua língua vernácula em certo lugar, mas o conjunto da população desse lugar não precisa nem a aprender nem a usar. Exemplos de diglossia sem bilinguismo são raros hoje em dia, pois, para tal, a maior parte da comunidade deverá desconhecer o código que cumpre as funções de variedade alta. Algo assim teria acontecido na Rússia antes da Revolução, onde a elite falava francês, que o resto da população não sabia. Ainda mais raros são os casos de ausência de bilinguismo e diglossia, que se restringem a sociedades isoladas (cf. FISHMAN, 1967, p. 31-37).

Por mais que as teorizações do termo diglossia feitas por Ferguson e Fishman sejam contestáveis, como efetivamente foram e têm sido, continuam a ser o fundamento do que se entende até hoje por "diglossia".

\section{Críticas ao conceito de diglossia}

Como expusemos na seção anterior, Ferguson não forjou o termo diglossia do nada, mas este já tivera o seu significado especializado para dar nome a um estado sociolinguístico bem determinado: os usos

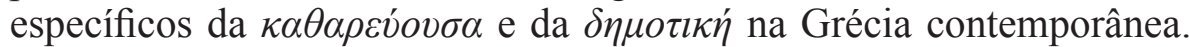
Curiosamente, a própria comunidade diglóssica prototípica veio contestar o começo da definição fergusoniana de diglossia em meados da década de setenta: a ditadura militar acabara havia dois anos; governava o primeiro-ministro Konstandínos Karamanlís e o Estado tinha uma nova constituição republicana. Nessa conjuntura, precisamente em 1976, uma

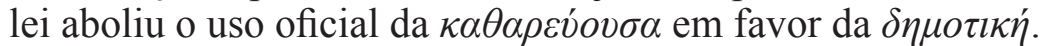

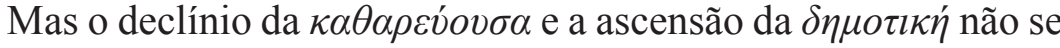
deram da noite para o dia. A consumação da mudança foi abrupta, mas o processo dela não. Desde o fim do século 19, ou seja, desde o próprio momento quando Roídis e Psichari usaram a palavra $\delta \imath \gamma \lambda \omega \sigma \sigma i \alpha$ para 
designar o estado sociolinguístico da Grécia, esse estado foi tornandose cada vez menos diglóssico, foi apresentando cada vez menos aqueles aspectos que, segundo Ferguson, configuram a diglossia. Quando

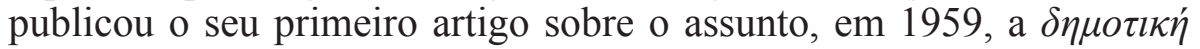
gozava já de considerável prestígio na sociedade grega, isso porque os escritores foram tornando-o paulatinamente veículo de expressão literária, o que produziu uma incipiente padronização (portanto uma diferenciação léxico-gramatical de base socioletal) que permitiu o seu ensino-aprendizagem pela educação formal. É claro que Ferguson não poderia ter previsto que a diglossia grega acabaria desaparecendo ao cabo de dezessete anos, mas certamente era um estado que se mostrava progressivamente menos estável.

Por outro lado, nos países árabes a diglossia permanece, mas também aí há apertos ou folgas na hora de aplicar a teorização de Ferguson sobre esse assunto. Se se enfoca o estado sociolinguístico dos países do Magrebe (ocidente do mundo árabe), constata-se que não se usam aí apenas o árabe padrão e o árabe vernáculo mas também línguas que são faladas aí desde antes da islamização - as línguas berberes - e uma língua implantada pela colonização europeia mais recente: o francês, e todas participam do jogo diglóssico. Há aí um verdadeiro solapamento de diglossias: o francês tem mais prestígio que o árabe padrão, este tem mais que o árabe vernáculo, este tem mais que a língua berbere (cf. SRHIR, 2005).

Não obstante, a limitação mais relevante, e também a mais tácita, da definição de Ferguson é o fato de depender de um problema da Linguística muito mais polêmico. Convém lembrar que, para Ferguson, a diglossia ocorre quando os códigos implicados são variedades da mesma língua. Mas o que distingue certo código como uma língua ou uma variedade de uma língua? Com efeito, um dos exemplos de Ferguson é o estado sociolinguístico do Haiti, onde o francês padrão seria a variedade alta e o crioulo seria a variedade baixa. Ora, é altamente questionável, de qualquer perspectiva, tratar o francês padrão e os crioulos de matriz francesa, não só o haitiano, como variedades de uma mesma língua.

Quanto à teorização de Fishman, resolveu em parte o problema dos estatutos dos códigos implicados no estado de diglossia: variedades da mesma língua ou línguas diferentes. Em parte porque se bem a aplicação do conceito no seu, digamos assim, "teto" (quando os códigos têm relação genética distante ou mesmo não têm) é fácil, permanece a possibilidade de a questionar no seu, digamos assim, "piso" (quando os códigos são 
considerados variedades de uma mesma língua). Se um estado diglóssico como o do Paraguai é indubitável, poder-se-ia questionar se há diglossia na relação entre o português brasileiro padrão e o português brasileiro vernáculo.

Por outro lado, essa teorização criou outros problemas. Perceba-se que a distinção entre as quatro situações sociolinguísticas que Fishman definiu - bilinguismo com diglossia, bilinguismo sem diglossia, diglossia sem bilinguismo e ausência de bilinguismo e diglossia - fundamenta-se sobre a extensão da comunidade em que uma ou outra situação se dá. Ora, a presença de uma população aloglota dentro de certa comunidade é um exemplo de bilinguismo sem diglossia com base na perspectiva de que essa população faz parte de uma comunidade na qual não há nem a necessidade de conhecer nem a necessidade de usar a língua de tal população. Contudo, também se pode assumir a perspectiva de que tal população forma uma comunidade por si, no seio da qual não ocorre bilinguismo sem diglossia, mas bilinguismo com diglossia, posto que dentro dela há a necessidade de conhecer e de usar a língua vernácula de origem e a língua vernácula da comunidade maior com funções sociais distintas. Do mesmo modo, se se considerarem comunidades por si as populações que usam línguas diferentes no estado de diglossia sem bilinguismo, ocorre ausência de bilinguismo e diglossia em cada uma, pois nelas é necessário conhecer e usar somente cada uma a sua própria língua.

$\mathrm{Na}$ verdade, o próprio fato de Fishman discernir o bilinguismo e a diglossia como fenômenos distintos é por si bastante interessante. Curiosamente, do ponto de vista etimológico, a palavra latina bilinguis é como que uma tradução da palavra grega $\delta \dot{\gamma} \gamma \lambda \omega \sigma \sigma o \varsigma$, uma tradução até mesmo da forma, pois o prefixo bis- equivale a $\delta \imath \sigma$-, que tem o mesmo significado de "duas vezes", e a raiz ling $u$ - equivale a $\gamma \lambda \omega \sigma \sigma-$, que tem o mesmo significado de "língua". Efetivamente, a palavra bilinguis queria igualmente dizer "que tem duas línguas, maledicente, caluniador". Se bem o substantivo derivado fosse bilinguitas, o fato é que os termos diglossia e bilinguismo significam, etimologicamente, o mesmo, e o emprego de ambos acarreta a mesmíssima limitação: o pressuposto de uma dicotomia, quando a realidade sociolinguística costuma apresentar uma paisagem bem mais complexa do que uma relação binária (cf. FERNÁNDEZ, 1995, p. 181-185).

Enfim, cumpre esclarecer que para tecer essas críticas não é preciso estudar com afinco especial a literatura sobre a diglossia posterior a Ferguson (1972 [1959]) e Fishman (1967). O próprio Ferguson (1972 [1959]) 
demonstrou que estava consciente das falhas da sua teorização ao procurar antecipar-se à maioria das críticas que acabamos de tecer ao longo de todo o seu texto, mas sem oferecer uma contra-argumentação avant la lettre.

Sem dúvida, um dos aspectos da teorização fergusoniana da diglossia que incomodou mais os sociolinguistas que depois se dedicaram ao assunto foi a estabilidade, entendida como uma fronteira pacata entre os códigos envolvidos. Assim, quase ao mesmo tempo em que Fishman (1967) publicava o seu primeiro artigo sobre o conceito, dois sociolinguistas espanhóis, Lluís Vicent Aracil (1982[1965]) e Rafael Ninyoles (1969), naturais de uma região, Valência, onde a relação entre o uso da língua alta, o espanhol, e da baixa, o catalão (chamado aí valenciano), é tensa até hoje, desenvolveram a noção de "conflito linguístico": a diglossia é um conflito entre os usos de duas línguas, em que o uso de uma "língua dominante" (geralmente, a língua alta) vai sobrepondo-se ao uso de uma "língua dominada" (geralmente, a língua baixa). O conflito pode ser manifesto ou latente, mas independentemente disso, ele evolui em direção à "substituição linguística", ou seja, à suplantação do uso de uma língua pelo da outra, a não ser que se leve a cabo a favor da língua dominada uma política de "normalização linguística", isto é, a sua padronização, o que abrange tanto a sua codificação quanto a extensão do seu uso a âmbitos que até então lhe estavam vedados.

Outro aspecto que suscitou a crítica de outros sociolinguistas foi o fato de os códigos envolvidos em uma diglossia serem tratados como categorias discretas. Marcellesi (1981, p. 8, tradução nossa) argumenta: "Os elementos dos códigos linguísticos são amiúde mais ou menos A, mais ou menos B, mais ou menos prestigiosos, mais ou menos minorizados". ${ }^{9}$ Empregando a mesma palavra que esse autor, a "mixagem" (mixage) é constitutiva da linguagem. Daí outro sociolinguista francês, Lambert-Félix Prudent (1981), defender que a diglossia não consiste em uma dicotomia entre um "acroleto" e um "basileto", mas trata-se mais propriamente de um continuum de "mesoletos", também a necessidade de discernir o "interleto", isto é, o uso linguístico híbrido resultante da diglossia. Tendo estudado a diglossia entre o uso do francês e do crioulo na Martinica, ele conclui:

9"Les éléments des codes linguistiques sont souvent plus ou moins A, plus ou moins B, plus ou moins prestigieux, plus ou moins minorés". 
Tendo partido em busca da fronteira entre as glossias martiniquesas, não achamos nem linha de fratura nítida nem sistema escalonado. Rejeitaremos, pois, retomar por conta própria e sem precauções adjetivais firmes o velho conceito colonial de diglossia, que mascara mais que resolve problemas, e ficaremos por enquanto com a noção de zona interletal (PRUDENT, 1981, p. 34 , tradução nossa). ${ }^{10}$

Hamel e Sierra (1983) entendem que as falhas das teorizações da diglossia feitas por Ferguson e Fishman não são senão reflexo de uma dificuldade geral por parte do pensamento ocidental de lidar com a heterogeneidade da linguagem, da qual o multilinguismo é uma das manifestações. Não é à toa que na mitologia judaico-cristã o fato de os homens falarem várias línguas é um castigo divino: a contingência, constitutiva da prática linguageira humana, sempre foi vista como caos.

Esses autores argumentam ainda que as teorizações de Ferguson (1972 [1959]) e Fishman (1967) estão a serviço de quem detém a hegemonia em uma comunidade diglóssica, pois ao suporem um funcionalismo idílico, dão aparência de naturalidade a certa ideologia acerca do uso de dois ou mais códigos linguísticos em uma comunidade, segundo a qual um código deve ser usado para fazer umas coisas e outro, para outras. Os autores contra-arrestam essa ideologia, argumentando que os otomis, povo indígena do México, empregam tanto o otomi como o espanhol no discurso dominante e no dominado, ou, em outras palavras, nem toda prática discursiva ligada à cultura otomi tradicional é realizada em otomi, nem toda prática discursiva ligada à cultura nacional mexicana é realizada em espanhol.

Já Manzano (2003) opõe-se à definição da diglossia como uma situação. Para ele, a expressão situação linguística é uma tentativa de domar e emoldurar o uso de uma ou mais línguas de modo a servir bem a um estudo científico de base positivista. No entanto, o uso de uma ou mais línguas acontece pela confluência de forças diversas, que o tornam

\footnotetext{
10“'Parti à la recherche de la frontière entre les glossies martiniquaises, nous n'avons rencontré ni ligne de fracture nette, ni système échelonné. Nous refuserons donc de reprendre à notre compte et sans précautions adjectivales fermes le vieux concept colonial de diglossie qui masque plus de problèmes qu'il n'en résout, et nous nous tiendrons pour l'heure à la notion de zone interlectale" (PRUDENT, 1981, p. 34).
} 
eminentemente instável. Em vez disso, o autor citado prefere falar de paisagem linguística (ou sociolinguística). A metáfora é feliz por ser facilmente compreensível: é fácil discernir uma ordem em uma paisagem reduzida dentro de uma moldura; ao contrário, é difícil dar conta da complexidade de uma paisagem vista ao vivo.

Para ilustrar a sua argumentação, o autor evoca o uso do francês e do gallo no oriente da região francesa da Bretanha. É um caso de diglossia "clássica", isto é, de diglossia tal como definida por Ferguson (1972[1959]), envolvendo variedades da mesma língua: o francês é a variedade alta e o gallo, a baixa. Não obstante, Manzano observa que esses dois códigos não são duas categorias discretas, mas duas práticas que se imbricam: elementos gallésants podem aparecer até no francês usado pela elite de Rennes, a capital da região. Mesmo em casos de diglossia fishmaniana, envolvendo línguas diferentes, Manzano (2003, p. 9-13) faz ver que a situação é uma redução de uma paisagem mais complexa: dissemos antes que em Marrocos há um solapamento de diglossias consistentes em usos do francês, do árabe padrão, do árabe vernáculo e do berbere. Na verdade, isto é um pedaço da paisagem sociolinguística marroquina, a que se vê nas zonas mais urbanizadas; em contrapartida, nos vales do Alto Atlas se usa quase somente o berbere, ou seja, vai-se de uma situação "pluriglóssica" a uma outra quase "monoglóssica".

Com efeito, as paisagens sociolinguísticas podem apresentar-se tão barrocas que fica difícil discernir até mesmo qual código é a variedade alta em relação a outro, a baixa. Evocamos a paisagem sociolinguística do Marrocos, onde mais que uma diglossia ocorre uma "poliglossia", em que o francês é "A" em relação ao árabe padrão, que é "A" em relação ao árabe vernáculo, que é "A" em relação ao berbere. Tabouret-Keller (2006) expõe o caso da região italiana do Vale de Aosta, cuja língua vernácula é um dialeto franco-provençal, chamado tradicionalmente aí patoué (da palavra francesa patois), porém há cinco séculos a língua oficial tem sido o francês, ao qual se agregou mais recentemente o italiano, por ser um território da Itália desde 1861. O autor vale-se de uma pesquisa feita em 2002 , segundo a qual para $63 \%$ da população o italiano é a língua materna, para $23,63 \%$, o franco-provençal e para apenas $1,2 \%$, o francês. Assim, não se sabe muito bem qual é a posição do francês, porque para a generalidade da população ele não é senão uma língua segunda aprendida na escola. Está mais ou menos presente como língua alta devido à sua condição de língua cooficial, porém não há uma demanda efetiva do seu uso como "A". 


\section{A diglossia espanhol-catalão na Catalunha}

O catalão é hoje a língua vernácula do Departamento dos Pireneus Orientais (salvo a região de Fenouillèdes ${ }_{1}^{11}$ de língua vernácula occitana), na França; do Principado de Andorra, que é um Estado soberano; da comunidade autônoma da Catalunha (salvo a comarca do Vale de Aran, também de língua vernácula occitana), de um conjunto de municípios da comunidade autônoma de Aragão, conhecido como Franja de Aragão, por estarem rentes à fronteira com a Catalunha, da maior parte da Comunidade Valenciana (salvo as comarcas mais ocidentais e meridionais, de língua vernácula castelhana), de um conjunto de aldeias da região de Múrcia, localizado na serra de El Carche, ${ }^{12}$ e da comunidade autônoma das Ilhas Baleares, na Espanha; da cidade de Alghero, ${ }^{13}$ na ilha da Sardenha, que é uma região autônoma da Itália. Mais adiante o leitor encontrará as informações sobre o reconhecimento oficial e o uso do catalão em cada um desses territórios.

$\mathrm{O}$ catalão individuou-se em face do latim no mesmo estado sociopolítico das demais línguas românicas, isto é, desde o Império Romano seguiu-se escrevendo em uma norma padrão que era a continuação da língua que os grandes escritores dos séculos 1 a.C. e 1 d.C. tinham empregado, ou seja, o latim clássico, enquanto a fala continuou a mudar até a própria comunidade romper, no século 9 , com a norma literária, considerando desde então que o que falava era outra língua, o romance. Trata-se do testemunho do Artigo 17 dos cânones do Concílio de Tours, de 813, que chama rustica romana lingua à língua falada, na qual os clérigos deviam pregar (cf. NADAL, 1992; BADIA I MARGARIT, 2004, p. 65-108, 123-128).

Não obstante, os falantes dos romances (ou vulgares) demoraram mais cinco séculos a conceder a mesma dignidade do latim à sua língua e a distinguir os seus falares com a condição de línguas diferentes. Nesse caso, trata-se da onda de codificação que teve lugar no fim do século 14 e durante o 16, quando se escreveram os primeiros tratados de ortografia, de gramática e em defesa de certas línguas vulgares. Todavia, se no momento da "emergência" o que distingue, do ponto de vista social, uns

\footnotetext{
${ }^{11}$ Fenolhedés, em occitano, e Fenolledès, em catalão.

${ }^{12}$ El Carxe, em catalão.

${ }^{13}$ L'Alguer, em catalão.
} 
romances e outros é a data, em uns casos mais adiantada e em outros mais serôdia, no momento da codificação havia romances em que se tinha acumulado um patrimônio literário considerável e que tinham sido assentados em um centro de poder, e outros que, ofuscados por esses, permaneceram, como ainda permanecem, à margem, mergulhando em outra diglossia, ocupando essa outra língua românica que alcançava a codificação o papel que fora do latim. Do primeiro caso, podem-se citar o português, o castelhano (mais tarde também "espanhol"), o francês, o toscano (mais tarde "italiano"). Do segundo, o leonês, sob o espanhol; o occitano, sob o francês; o vêneto, sob o italiano. A singeleza da história do catalão começa por aqui (cf. NADAL, 1999).

Por um lado, a sua comunidade rejeitou, em princípio, o cultivo da poesia culta nele, usando o occitano, vizinho e quase gêmeo, mas desenvolveu uma prosa que sobressai perante outras coevas em língua vulgar porque veiculou, inclusive, a especulação filosófica (obra de Raimundo Lúlio), terreno privado da língua culta, o latim. Quando a poética trovadoresca se abriu ao Dolce Stil Novo italiano, trocou o occitano pela língua vernácula e engendrou um poeta influente no humanismo ibérico: Ausiàs March (cf. BADIA I MARGARIT, 2004, p. 183-288).

Por outro lado, às vésperas da onda de codificação, a comunidade catalanófona rompeu a tradição literária ao rechaçar a poética trovadoresca sob a escusa de que estava escrita em uma língua antiga, o "limusino". Cabe lembrar que o continuum geoletal catalão não correspondia a um só ente territorial, mas a reinos autônomos, federados sob um mesmo monarca: a Coroa de Aragão. A codificação poderia, então, ter-se feito a partir do centro de poder que constituía a corte, como ocorrera, a propósito, na prosa, cujos cultores dispunham do modelo de língua da Chancelaria Real, outro fator favorável que possuía a língua catalã para a sua codificação. Contudo, no século 16 não havia mais centro de poder que coerisse o continuum, já que ele estava fora, em Castela, devido à união da Coroa de Aragão com esta outra, centro que atraía a comunidade catalanófona a si e à língua que emanava: o castelhano, que logo se tornaria a expressão de uma literatura pujante. Consequência de tudo isso é que ficou à margem da onda de codificação e foi sendo sujeitado a uma diglossia com o castelhano que veio consolidar-se em 1707-1716, quando o rei Filipe V, que venceu a Guerra de Sucessão Espanhola e instaurou a dinastia de Bourbon, aboliu as instituições dos estados da antiga Coroa de Aragão, inclusive o uso oficial do catalão (cf. NADAL, 1992). 
Portanto, o catalão acabou a Idade Média com plenas condições de se tornar uma das "grandes" línguas românicas, mas perdeu tudo ao longo da Idade Moderna, de modo que, ao começar a Idade Contemporânea, achava-se na condição social de um dialeto. Porém, nesse momento, a comunidade catalanófona, que mantinha bem viva a lembrança do esplendor medieval, não só recobrou o cultivo literário da sua língua - a Renaixença - como também, a partir disso, construiu uma identidade nacional alternativa à espanhola, promovida pelo nacionalismo estatal. Foi precisamente no momento em que o nacionalismo catalão, ou catalanismo, alcançou o poder em 1907, restaurando administrativamente a Catalunha na forma da "mancomunidade" em 1914, que os catalães, sob a liderança de Enric Prat de la Riba, o seny ordenador ("siso ordenador"), aproveitaram o ensejo e deram outra guinada à história da sua língua. Prat não fundou nenhuma academia nova (já havia a Acadèmia de Bones Lletres de Barcelona, ligada à ideologia tradicionalista dos Jocs Florals ("Jogos Florais")), mas uma instituição de pesquisa, à qual entregou a autoridade de codificar o catalão: o Institut d'Estudis Catalans (IEC), cuja Seção Filológica foi criada em 1911. Na execução da tarefa, cujo primeiro produto foram as Normes ortogràfiques de 1913, impôs-se outro siso ordenador: Pompeu Fabra, que publicou, a serviço do IEC, a gramática normativa (Gramàtica catalana) e o dicionário normativo (Diccionari general de la llengua catalana), respectivamente em 1918 e 1932 (cf. BADIA I MARGARIT, 2004, p. 477-562).

Quando toda a construção política do catalanismo desmoronou em 1939, início da ditadura nacionalista do general Francisco Franco, a obra de Fabra era tão firme que acabou consolidando-se pelas penas de todos aqueles que se opuseram à conjuntura cultivando literariamente a língua catalã. $\mathrm{O}$ segredo do seu sucesso não foi apenas o seu rigor filológico mas também, e julgo que decisivamente, a sua atitude perante a padronização, o que vem opor a padronização do catalão à do galego, ocorrida no mesmo quadro histórico, político e social que é a Espanha: enquanto a comunidade galegófona legitimou a diglossia ao padronizar o galego como se vinha escrevendo, isto é, com base na norma padrão do castelhano, a comunidade catalanófona, pelo trabalho de Fabra, procurou padronizar o catalão como se não tivesse havido a Decadência literária, como se não estivesse sujeito ao castelhano. O catalão deveria ser tão diferente e tão independente deste como qualquer uma das demais "grandes" línguas românicas (cf. LAMUELA; MURGADES, 1984). 
Hoje, a língua catalã possui algum grau de reconhecimento oficial em todos os territórios onde é língua vernácula: é a única língua oficial no Principado de Andorra; é oficial com o castelhano nas comunidades autônomas espanholas da Catalunha, das Ilhas Baleares e Valenciana; deve ser promovida e pode ser usada pelo governo municipal em Alghero; é protegida nos municípios aragoneses que compõem a Franja de Aragão; é promovida no departamento francês dos Pireneus Orientais. Contudo, o catalão não é falado, hoje, pela generalidade dos habitantes desses territórios. A porcentagem de falantes varia de uma grande maioria na Franja de Aragão (88,8\%), na Catalunha (84,7\%) e em Andorra (78,9\%) a pouco mais que a metade em Alghero $(61,3 \%)$ e na Comunidade Valenciana $(58,4 \%)$ e a uma minoria no departamento dos Pireneus Orientais $(37,1 \%)$. Isso se deve, sobretudo, a duas causas: a imigração e a ação do Estado (cf. QUEROL, 2007, p. 184).

De fato, desde o fim da Segunda Guerra Mundial todos os territórios de língua catalã receberam uma grande quantidade de imigrantes aloglotas que, como o catalão estava arrincoado à informalidade, não precisaram aprendê-lo. Os catalófonos acomodaram-se à ideia de que eram eles que tinham de usar a língua estatal para comunicar com quem não sabia a sua. De fato, 55,4\% da população do departamento dos Pireneus Orientais não nasceu aí, 50,9\% da população de Andorra, $40,1 \%$ da população das Ilhas Baleares, $34,4 \%$ da população de Alghero, $31,1 \%$ da população da Comunidade Valenciana, $28,1 \%$ da população da Catalunha e $11 \%$ da população da Franja de Aragão (cf. QUEROL, 2007, p. 19).

Segundo Querol (2007, p. 187), a interação linguística na comunidade catalanófona pauta-se pelas normas sociais seguintes:

i. entre pessoas que consideram que o catalão é a sua língua, a interação dá-se quase exclusivamente nessa língua, salvo em Alghero, onde o italiano penetrou até mesmo aí;

ii. entre pessoas que consideram que o catalão é a sua língua e outras que consideram que a sua língua é a oficial do Estado, dá-se majoritariamente nessa outra língua;

iii. entre os jovens, há uma tendência a passar à língua do interlocutor em Andorra e na Catalunha; e

iv. há um número elevado de pessoas que passam ao catalão quando, tendo começado uma conversa na língua oficial do Estado, o interlocutor lhe responde em catalão, pelo que se 
supõe que poderia haver mais interação em catalão se se mantivesse o seu uso nessa situação.

\section{Repensando o sujeito falante da variedade baixa / língua dominada}

Na seção anterior, fizemos um percurso crítico sobre o conceito de diglossia que se estendeu desde as próprias brechas da sua construção por Ferguson (1972[1959]) e Fishman (1967) até leituras que a questionaram de modo mais perspicaz, pelos seus pressupostos. A crítica que viemos apresentar neste trabalho procede de ainda mais longe, pois parte do questionamento da própria episteme da Sociolinguística. Efetivamente, já em 1984 Gimeno Fernández (p. 61, tradução nossa) arguia que

[o]s fenômenos do multilinguismo - o bilinguismo, em geral - são demasiado complexos e diversos para serem interpretados de uma perspectiva disciplinar. Inicialmente poderíamos assumir que a repartição dos usos linguísticos é social e a sua descrição corresponde à sociologia, a filiação diferencial das suas aplicações é linguística, e a análise dos seus polos de repartição corresponde à psicologia da comunidade de fala $\mathrm{e}$ do falante. Igualmente outros aspectos do problema, como as questões pedagógicas, políticas, jurídicas, geográficas e culturais não deveriam faltar em qualquer reflexão séria. ${ }^{14}$

Nesse sentido, a minha crítica da diglossia segundo Ferguson (1972[1959]) e Fishman (1967) ultrapassa não só as fronteiras da Sociolinguística, mas da própria Linguística: fundamentamo-nos na reflexão de Michel de Certeau (1994) acerca do cotidiano.

\footnotetext{
14““[1]os fenómenos del multilingüismo - o bilingüismo, en general - son demasiado complejos y diversos para ser interpretados desde una perspectiva disciplinaria. Inicialmente podríamos asumir que la repartición de los usos lingüísticos es social y su descripción corresponde a la sociología, la filiación diferencial de sus aplicaciones es lingüística, y el análisis de sus polos de repartición corresponde a la psicología de la comunidad de habla y del hablante. Asimismo otros aspectos del problema, como las cuestiones pedagógicas, políticas, jurídicas, geográficas y culturales no deberían faltar en cualquier reflexión seria".
} 
Ao longo de todo este trabalho, temos empregado repetidamente a palavra uso. O objeto da reflexão de Certeau (1994) é precisamente o uso. A vivência humana constitui-se de usos, de fazeres, ou, mais precisamente, de um constante e variado "fazer com". Quando Aracil (1982[1965]) e Ninyoles (1969) elaboraram a noção de conflito linguístico, deram uma boa precisão sociológica ao conceito de diglossia, que tinha um embasamento estritamente funcionalista, e que com os termos alto e baixo acabou institucionalizando a crença de que há códigos linguísticos superiores e outros inferiores, para dizer o mínimo. Contudo, afora o questionamento da estabilidade, a noção de conflito linguístico consiste tão somente em uma troca de termos convenientes à hegemonia por outros convenientes àqueles que defendiam a cultura sujeita a um jugo colonial: "variedade alta" por "língua dominante" e "variedade baixa" por "língua dominada". Não obstante, a base dicotômica da diglossia acabou reforçando-se: há um agente, o dominante, e um paciente, o dominado. Falando de usos, Certeau (1994) convida precisamente a refletir que o dominado não é tão dominado quanto parece à primeira vista.

A paisagem sociolinguística que escolhemos para dar fundamento e exemplo da nossa crítica - os usos do espanhol e do catalão na Catalunha - é especialmente apropriada, porque há aí um reconhecimento legal de que apenas uma das línguas é a própria da comunidade: trata-se do Parágrafo 1 do Artigo 6 do Estatuto de Autonomia da Catalunha, que estabelece que a língua própria da Catalunha é o catalão. Isso pressupõe que a presença da língua oficial do Estado é tida como uma imposição colonial, que não participa da identidade nativa. Muito curiosamente, Certeau (1994, p. 99-100) vale-se de um conceito ao qual chama próprio para argumentar que o receptor não é apenas um receptáculo, mas um receptor que "faz com" o que lhe é transmitido coisas que o tornam agente dentro da própria relação em que parece ser apenas paciente. Certeau (1994, p. 92-93) dá o exemplo do sucateiro, que refuncionaliza o que recebe da indústria de peças metálicas. O sucateiro é partícipe do sistema hegemônico ao mesmo tempo que está submetido a ele. A diferença entre a agência da indústria de peças metálicas e a do sucateiro reside no fato de que este age em um espaço e em um tempo que pertencem àquela, ou, empregando o referido conceito de próprio, a indústria de peças metálicas tem um próprio, enquanto o sucateiro age no alheio. À agência no "próprio", dá Certeau (1994, p. 97-106) o nome de estratégia e, à no alheio, o de tática: 
As estratégias são portanto ações que, graças ao postulado de um lugar de poder (a propriedade de um próprio), elaboram lugares teóricos (sistemas e discursos totalizantes), capazes de articular um conjunto de lugares físicos onde as forças se distribuem. [...] As táticas são procedimentos que valem pela pertinência que dão ao tempo - às circunstâncias que o instante preciso de uma intervenção transforma em situação favorável, à rapidez de movimentos que mudam a organização do espaço, às relações entre momentos sucessivos de um "golpe", aos cruzamentos possíveis de durações e ritmos heterogêneos etc. (CERTEAU, 1994, p. 102).

Cumpre reconhecer que o par próprio $\mathrm{x}$ alheio não deixa de constituir categorias dicotômicas, às quais nos temos contraposto. Não obstante, em vez de o rejeitar, cremos que convém aceder ao raciocínio de Mignolo (2003, p. 150, tradução nossa), segundo o qual pode ser coerente, mesmo de uma perspectiva crítica, "[p]ensar a partir de conceitos dicotômicos em lugar de ordenar o mundo em dicotomias". ${ }^{15}$

Portanto, quando um catalão diz - em espanhol - algo como:

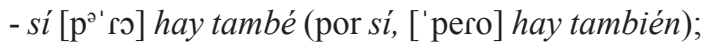

- ['ara] no son comunistas (por [a'ora] no son comunistas);

- ves que hay ['barjus] (por ves que hay ['barjos]);

- el conoces (por lo conoces)

- es drogan muchísimos, los italianos que vienen aquí, alucinas (por se drogan muchísimos, los italianos que vienen aqui, alucinas);

- l'único que veo es... (por lo único que veo es...);

- depén a qué zona te vayas (por depende a qué zona te vayas);

- lo hacían siempre, cada noche, cada noche (por lo hacían siempre, todas las noches, todas las noches);

- ¡molt bé! (por ¡muy bien!);

- a casa per deberes (por en casa por deberes);

- hay días que plego a las 8 y 20 (por hay días que salgo a las 8 y 20), (apud WIELAND, 2008, p. 155-179),

submete-se a uma dominação, mas também lhe dá um golpe astucioso, empoderando a sua posição de fraco. No momento em que o catalão se comunica em espanhol, integra-se à comunidade de língua espanhola,

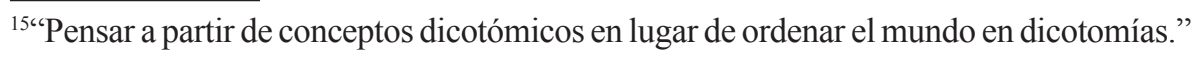


hegemônica no Estado do qual é cidadão, mas o hibridismo do espanhol que usa conserva a sua alteridade em face dos demais espanhóis, ou, dito de outra maneira, conserva a sua identidade distintiva, que a dominação procura, precisamente, esconder ou apagar. Submete-se à dominação, mas ao mesmo tempo a subverte a favor de si. A diglossia entre o uso do espanhol e do catalão na Catalunha é o efeito de estratégias do Estado espanhol com o fim de estabelecer um Estado jacobino, que se identifica com uma só nação e uma só língua. O hibridismo do espanhol usado pelo catalão é uma tática que contra-arresta a diglossia. Como dissemos antes, o dominado não é tão dominado assim, mas (re)age e tira proveito da sua fraqueza.

O hibridismo como tática apresenta ainda outro aspecto interessante: também é um contraponto à ideologia que exclui o imposto pela dominação do próprio, ou seja, ao preceito tácito, mesmo negado, de que não se pode ser catalão senão falando catalão, preceito que é verdadeiro, visto que é uma demanda social constatável, mas que é questionável na medida que a estratégia de uniformização é burlada.

\section{Considerações finais}

Apesar do rio de tinta que as críticas às definições de diglossia segundo Ferguson e Fishman já verteram, tal conceito continua a ser muito pertinente como ponto de partida de uma reflexão sobre os usos de dois ou mais códigos linguísticos em uma comunidade, o que, de resto, caracteriza, hoje, a maior parte das paisagens sociolinguísticas pelo mundo. Não há por que deixar de se falar em diglossia para nomear essas paisagens sociolinguísticas, contanto que o sociolinguista esteja comprometido com afinar cada vez mais o seu aparelho teóricometodológico para não subestimar a complexidade da diglossia.

O conceito linguístico de diglossia foi desenvolvido originariamente para nomear uma realidade particular, em que uma comunidade empregava duas variedades consideravelmente diferentes da mesma língua, cada uma julgada apropriada a certos âmbitos, constituindo a fronteira entre esses âmbitos principalmente a formalidade. Trata-se, como já se sabe, da realidade da Grécia após a formação do Estado grego moderno.

Por semelhança com essa realidade, o conceito começou a ser empregado para designar outras realidades, até a incipiente ciência sociolinguística perceber que ele poderia servir ao seu escopo. Porém, 
ao mesmo tempo que supria uma necessidade teórica, a cientificização desse conceito acarretou o problema de lidar com a contingência do uso da linguagem, algo especialmente difícil, já que não requer apenas uma teoria de pontas bem amarradas (o que, de resto, nem a de Ferguson (1972 [1959]) nem a de Fishman (1967) são), mas uns pressupostos teóricos suficientemente maleáveis. Alguns autores que resenhamos sumariamente procuram fazer isso, mantendo-se dentro da disciplinaridade da (Socio) Linguística. Nós, em contrapartida, escrevemos estas linhas para uma reflexão mais ousada, que recorreu ao pensamento de Michel de Certeau (1994), portanto fora da (Socio)Linguística estrita, para repensar principalmente o sujeito falante da "variedade / língua baixa" ou "língua dominada".

O repensar esse sujeito leva-nos ao entendimento de que ele não é apenas um paciente das relações assimétricas de poder constituídas pela diglossia e que a constituem mas também um agente que dribla as estratégias dos agentes hegemônicos, refuncionalizando-as em proveito próprio. Trouxemos essa reflexão para o estudo da diglossia, observando que o hibridismo presente no espanhol falado pelos catalães pode constituir uma tática mediante a qual o sujeito falante da "língua dominada" pode, ao mesmo tempo, aceitar o jogo diglóssico e burlá-lo, pois, se esse jogo se encaminha, em última instância, à incorporação do diferente (o catalão aloglota), ao igual (a comunidade hispanófona), o diferente permanece, assim, diferente, ainda que aparentemente incorporado.

É claro que esta reflexão não pretende, absolutamente, questionar a legitimidade de uma política com o fim de "normalizar" o uso do catalão, porque a alteridade dos catalães em face dos espanhóis também se pode manifestar falando espanhol. O hibridismo desse espanhol é um tática mediante a qual se mantém essa alteridade, porque há uma assimetria: uma assimetria linguística entre o espanhol e o catalão que constitui e é constituída por uma assimetria política entre a Espanha e a Catalunha, as quais a sociedade catalã tem todo o direito de questionar e mudar se assim o desejar.

\section{Referências}

ARACIL, L.V. (1965). Papers de sociolingüística. Barcelona: La Magrana, 1982, p. 23-28. 
BADIA I MARGARIT, A. M. Moments clau de la història de la llengua catalana. Valência: Universitat de València, 2004.

CERTEAU, M. de. A invenção do cotidiano: Artes de fazer. Petrópolis: Vozes, 1994.

FERGUSON, C. A. (1959). Diglossia. In: GIGLIOLI, P. P. (Org.). Language and social context: Selected readings. Baltimore: Penguin, 1972. p. 232-251.

FERNÁNDEZ, M. Los orígenes del término diglosia: Historia de una historia mal contada. Historiographia Linguistica, v. 22, n. 1-2, p. 163195,1995.

http://dx.doi.org/10.1075/hl.22.1-2.07fer

FISHMAN, J. A. Bilingualism with and without diglossia; diglossia with and without bilingualism. Journal of Social Issues, v. 23, n. 2, p. 29-38, 1967.

http://dx.doi.org/10.1111/j.1540-4560.1967.tb00573.x

GIMENO FERNÁNDEZ, F. Multilingüismo y multilectismo. E.L.U.A., n. 2, p. 61-89, 1984.

HAMEL, R. E.; SIERRA, M. T. Diglosia y conflicto intercultural: La lucha por un concepto o la danza de los significantes. Boletín de Antropología Americana, n. 8, p. 89-110, 1983.

LAMUELA, X.; MURGADES, J. Teoria de la llengua literària segons Fabra. Barcelona: Quaderns Crema, 1984.

MANZANO, F. Cahiers de sociolinguistique, n. 8, p. 1-15, 2003.

MARCELLESI, J.-B. Bilinguisme, diglossie, hégémonie : problèmes et tâches. Langages, v. 15, n. 61, p. 5-11,1981.

http://dx.doi.org/10.3406/lgge.1981.1865

MIGNOLO, W. D. Historias locales / dise-os globales: colonialidad, conocimientos subalternos y pensamiento fronterizo. Madrid: Akal, 2003.

NADAL, J. M. Llengua escrita i llengua nacional. Barcelona: Quaderns Crema, 1992.

NADAL, J. M. Normativa i història de la llengua. In: FELIU, Francesc; JUHER, Cristina (Org.). La invenció de les llengües nacionals. Barcelona: Quaderns Crema, 1999. 
NINYOLES, R. Conflicte lingüistic valencià. València: Tres i Quatre, 1969.

PRUDENT, L.-F. Diglossie et interlecte. Langages, v. 15, 1981, p. 13-38. http://dx.doi.org/10.3406/lgge.1981.1866

QUEROL, E. (org.). Llengua i societat als territoris de parla catalana a l'inici del segle XXI: L'Alguer, Andorra, Catalunya, Catalunya Nord, la Franja, Illes Balears i Comunitat Valenciana. Barcelona: Generalitat de Catalunya, 2007.

SRHIR, A. M. La diglosia y la poliglosia como proceso de subordinación lingüística: estudio del caso de Marruecos. Estudios de Dialectología Africana y Andalusí, n. 9, p. 139-149, 2005.

TABOURET-KELLER, A. À propos de la notion de diglossie. La malencontreuse opposition entre "haute" et "basse": ses sources et ses effets. Langage et société, v. 4, nº 118, p. 109-128, 2006.

WIELAND, K. Transgresiones lingüísticas bidireccionales: el lenguaje juvenil entre el castellano y el catalán. In: SINNER, C.; WESCH, A. (Ed.). El castellano en las tierras de habla catalana. Madri: Iberoamericana; Frankfurt am Main: Vervuert, 2008. p. 155-17 